\section{DAMPAK REVITALISASI TERHADAP KARAKTERISTIK BERLOKASI PKL DI KOTA LAMA SEMARANG}

\author{
Dwirantika Maharani Putri Susetya*, Santy Paulla Dewi \\ Departemen Perencanaan Wilayah dan Kota, Fakultas Teknik, \\ Universitas Diponegoro, Indonesia
}

\author{
Jurnal Pengembangan Kota (2021) \\ Volume 9 No. 2 (192-203) \\ Tersedia online di: \\ http://ejournal2.undip.ac.id/index.php/jpk \\ DOI: 10.14710/jpk.9.2.192-203
}

\begin{abstract}
Abstrak. Revitalisasi Kota Lama Semarang yang dilakukan dalam rangka menghidupkan kembali kawasan turut mempengaruhi PKL dalam berlokasi di Kawasan tersebut. Penataan PKL yang dilakukan pasca revitalisasi tidak membuat PKL berhenti berjualan dan justru membuat PKL menyesuaikan kegiatannya agar tetap dapat berjualan. Penelitian ini dilakukan untuk menganalisis karakteristik berlokasi PKL pasca revitalisasi Kota Lama Semarang. Metode penelitian yang digunakan yaitu pendekatan kuantitatif dengan teknik analisis meliputi analisis deskriptif, analisis kebijakan penataan PKL pasca revitalisasi, dan analisis spasial berupa overlay. Hasil penelitian menunjukkan bahwa karakteristik berlokasi PKL adalah pada trotoar, persimpangan jalan, taman, jalan utama dan jalan penghubung kawasan yang terdapat kepadatan pejalan kaki, pada lokasi yang memiliki berbagai aktivitas di sekitarnya, terdapat akumulasi pengunjung dan terdapat kelonggaran pengawasan petugas yang mengawasi PKL. Perubahan karakteristik PKL sebelum dan sesudah revitalisasi terlihat pada adanya penyesuaian (perubahan) dalam hal jenis dagangan, sifat layanan, sarana usaha, dan waktu operasional berjualan. Mayoritas merupakan PKL keliling menggunakan sarana usaha yang mudah dibawa, serta berjualan makanan minuman siap konsumsi dan barang non-makanan, dengan waktu operasional yaitu pada sore hingga malam hari.
\end{abstract}

Kata Kunci: Karakteristik Berlokasi; Kota Lama Semarang; PKL; Revitalisasi

[Title: The Revitalization Impact on the Characteristics of Street Vendor Location in Semarang Old Town]. The Semarang Old Town revitalization was conducted to revive the area also as well as to arrange the location of street vendors. After the revitalization step 1, there is a restriction for the street vendors to locate in the Old Town. However, this restriction did not make the street vendors move from the previous location, they were existed and tried to adjust to the situation. This study was conducted to analyze the characteristics of street vendors locations after the revitalization of Semarang Old Town. The research method used a quantitative approach with analytical techniques including descriptive analysis, policy analysis of post-revitalization street vendors arrangement, and spatial analysis. The results showed that the characteristics of street vendors location are on the sidewalks, crossroads, parks, main roads, and connecting roads in areas where there are a lot of pedestrians, in locations that have various activities, have an accumulation of visitors, and less supervision from the officers. The changes of street vendors characteristics before and after revitalization can be seen from the adjustment of type of commodity, serving method, trade facilities, and operating hours. Most street vendors are included as mobile street vendors with easy-to-carry trade facilities and selling food and beverages as well as non-food items, with operating hours in the afternoon to evening.

Keywords: Location Characteristics; Revitalization; Semarang Old Town; Street Vendors

Cara Mengutip: Susetya, Dwirantika Maharani Putri., \& Dewi, Santy Paulla. (2021). Dampak Revitalisasi Terhadap Karakteristik Berlokasi PKL di Kota Lama Semarang. Jurnal Pengembangan Kota. Vol 9 (2): 192-203. DOI: 10.14710/jpk.9.2.192-203

\section{PENDAHULUAN}

Pedagang kaki lima (PKL) merupakan salah satu kegiatan ekonomi informal perkotaan yang sering sekali ditemui di ruang publik perkotaan, seperti pada persimpangan jalan, trotoar, taman lingkungan, badan jalan, dan atau pada ruang publik lainnya yang memungkinkan dapat dengan mudah dilakukannya interaksi antara penjual dengan pembeli. Keberadaannya yang cenderung berlokasi pada ruang publik tersebut sering kali menimbulkan konflik pemanfaatan ruang karena keberadaannya pada badan jalan dapat menimbulkan kemacetan, keberadaannya pada 
trotoar menyebabkan terganggunya pejalan kaki, dan munculnya pencemaran lingkungan yang disebabkan dari keberadaan aktivitas PKL yang kurang menjaga kebersihan lingkungan (Widjajanti, 2012). PKL yang cenderung menempati ruang publik perkotaan dan menimbulkan berbagai permasalahan baru tersebut kemudian menjadikan kegiatan ekonomi ini identik sebagai kegiatan yang ilegal dan dianggap sebagai wabah perkotaan yang harus ditangani (Ojeda \& Pino, 2019). Namun, di sisi lain keberadaan PKL yang termasuk sektor informal ini pada dasarnya membantu mengatasi permasalahan keterbatasan lapangan pekerjaan di perkotaan dan keterbatasan kemampuan tenaga kerja untuk bersaing dalam sektor formal (Perdana dkk., 2020) karena dapat menciptakan lapangan pekerjaan dan membantu angkatan kerja di perkotaan untuk mendapatkan penghasilan (Todaro \& Smith, 2006). Oleh sebab itu, keberadaan PKL di perkotaan ini kemudian menjadi tantangan baru bagi perkotaan untuk menciptakan perencanaan kota yang bersifat inklusif (Roever \& Skinner, 2016) agar kegiatan PKL dapat tetap berjalan dan memberikan manfaat bagi perkotaan tanpa menimbulkan permasalahan baru bagi perkotaan itu sendiri.

Pemerintah Kota Semarang juga melakukan penataan PKL di Kota Lama sebagai bagian dari upaya revitalisasi tahap 1. Revitalisasi Kota Lama Semarang dimulai pada tahun 2017 dengan melakukan perbaikan sarana prasarana, penambahan signage dan street furniture. Pasca revitalisasi Kota Lama Semarang terdapat larangan untuk berjualan di sekitar kawasan bersejarah tersebut, yang ditegaskan dalam papan penanda larangan berjualan yang tersebar di beberapa titik lokasi. Penataan PKL dilakukan dalam rangka untuk menjaga kebersihan sekaligus menjaga wajah kawasan yang sudah baik pasca revitalisasi. Hal ini diwujudkan dengan merelokasi PKL ke tempat yang disediakan yaitu di gedung Galeri Industri Kreatif Semarang (sekarang Semarang Creative Hub. Sebagian besar PKL yang ditempatkan dilokasi tersebut adalah para pedagang barang antik yang sebelumnya berjualan di Jalan Taman Srigunting. Sedangkan PKL lain seperti yang berjualan makanan dan minuman maupun PKL jenis lain tidak terakomodasi. PKL ini kemudian mencari lokasi berjualan yang merupakan titik-titik keramaian. Keberadaan PKL yang tidak terakomodasi ini yang kemudian mengalami perubahan setelah adanya revitalisasi dan menjadi fokus dari kajian ini.

Kegiatan penataan PKL, khususnya berupa penertiban tersebut menunjukkan bahwa keberadaan PKL dianggap out of place karena dapat menimbulkan ketidakserasian antara fisik lingkungan dengan estetika visual lingkungan (Creswell, 1996; Hough, 1990; Yatmo, 2008) dalam (Widjajanti dkk., 2017). Oleh sebab itu, upaya penataan PKL ini kemudian diwujudkan melalui adanya pemindahan ke lokasi lain. Penentuan lokasi baru kurang mengakomodasi kepentingan PKL sehingga menimbulkan protes dari PKL atau lokasi baru tersebut kemudian tidak ditempati dan memilih kembali ke lokasi semula meski harus menghadapi kemungkinan dirazia oleh aparat (Nogueira, 2021; Turner \& Zuberec, 2021). Seperti halnya kebijakan pemerintah Kota Semarang yang melarang PKL untuk berjualan di Kota Lama Semarang, namun di sisi lain ramainya kunjungan wisawatan menyebabkan para PKL memilih tetap berjualan di kawasan tersebut. Para PKL menyesuaikan cara berjualan mereka untuk meminimalkan kemungkinan terkena penyitaan barang saat dilakukannya kegiatan penertiban secara tiba-tiba.

Penelitian terdahulu yang dilakukan oleh Suryanto dkk. (2020), menunjukkan bahwa pengaruh dari penataan PKL yang dilakukan dengan penggusuran menyebabkan PKL mengincar lokasi baru yang masih dapat diakses oleh pelanggannya dan pada lokasi yang ramai pengunjung. Sementara itu, penelitian yang dilakukan oleh Perdana dkk. (2020) menunjukkan bahwa meskipun sudah terdapat upaya relokasi, para PKL cenderung akan kembali ke lokasi sebelumnya karena lokasinya yang sudah sesuai dengan karakteristik PKL. Pemilihan lokasi PKL sendiri berdasarkan penelitian yang dilakukan

ISSN 2337-7062 @ 2021

This is an open access article under the CC-BY-NC-ND license (http://creativecommons.org/licenses/by-nc-sa/4.0/). - lihat halaman depan (C) 2021

*Email dwirantika10@gmail.com

Diterima 16 Juli 2021, disetujui 30 November 2021 
oleh Santos dkk. (2020) dipengaruhi oleh logistic (aksesibilitas, keadaan demografi sekitar, dan tempat tertutup untuk berbelanja), marketplace attraction (ethnicity, jenis tempat jualan, dan suasana sekitar), dan shopping attributes (keyakinan pribadi, potensi tawar-menawar, serta diferensiasi produk dan penjualan). Karakteristik lokasi PKL lainnya yaitu dekat dengan kegiatan utama, dekat dengan jalan atau mudah diakses, dan pada lokasi strategis dengan beragam aktivitas (Rahayu dkk., 2019; Widjajanti dkk., 2017). Adapun lokasi yang diminati oleh PKL sebagaimana dikemukakan oleh Deore and Lathia (2019) dalam penelitiannya yaitu PKL cenderung berjualan di sepanjang jalan kolektor atau jalan lokal, di trotoar, dan pada lokasi yang terdapat penutup kanopi.

Penelitian terdahulu membahas mengenai pengaruh upaya penataan PKL dan karakteristik lokasi PKL di berbagai lokasi. Namun, belum terdapat penelitian yang membahas mengenai pengaruh dari kegiatan revitalisasi Kota Lama Semarang terhadap karakteristik berlokasi PKL pada kawasan bersejarah tersebut. Karakteristik berlokasi yang dimaksud adalah karakteristik penggunaan ruang oleh PKL ketika berjualan pada suatu lokasi. Karakteristik berlokasi ini dipengaruhi oleh beberapa hal seperti lokasi, aktivitas apa yang ada di dekatnya, permintaan konsumen, kedekatan dengan transportasi atau aksesibilitas, waktu berjualan, dan ukuran tempat aktivitas yang disesuaikan berdasarkan jumlah komoditas yang ingin dijual. Hal tersebut kemudian melatarbelakangi dilakukannya penelitian ini, mengingat masih dapat ditemuinya PKL di kawasan bersejarah tersebut meskipun sudah ada kebijakan penataan PKL berupa larangan berjualan PKL di Kota Lama Semarang pasca revitalisasi.

\section{METODE PENELITIAN}

Lokasi penelitian ini berada pada area di sepanjang Koridor Jalan Letjen Suprapto Kota Lama Semarang dengan luas yaitu 7,5 Ha (lihat Gambar 1). Lokasi penelitian dipilih karena terdapat konsentrasi masyarakat atau pengunjung di sekitar Jalan Letjen Suprapto, khususnya di sekitar Taman Srigunting dan Jembatan Berok yang merupakan persimpangan jalan. Keberadaan konsentrasi masyarakat atau pengunjung tersebut kemudian menyebabkan adanya konsentrasi PKL di sekitar lokasi tersebut karena karakteristik PKL salah satunya yaitu berjualan pada lokasi yang terdapat akumulasi pengunjung (Widjajanti, 2015).

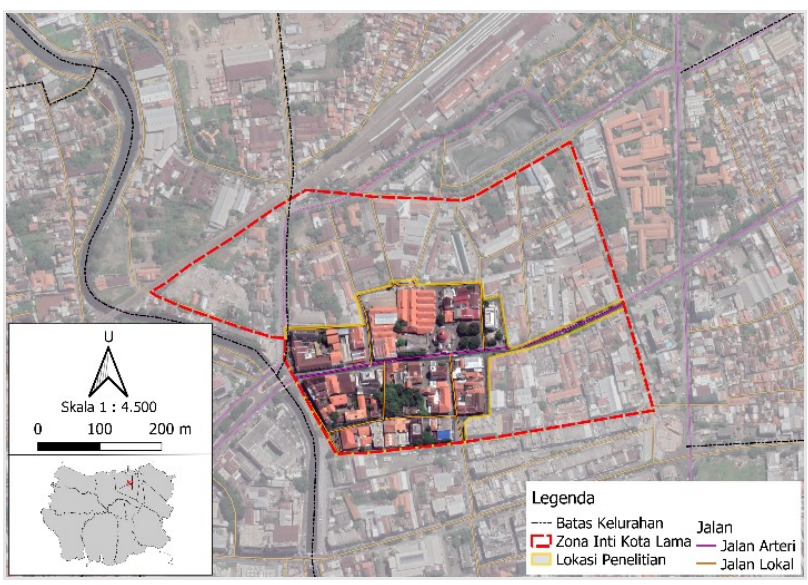

Gambar 1. Wilayah Studi Kota Lama Semarang

Metode penelitian kuantitatif digunakan pada penelitian ini dengan data yang digunakan yaitu berupa data primer dan data sekunder yang diperoleh dengan melakukan penyebaran kuesioner yang diikuti dengan kegiatan wawancara untuk menguatkan data, observasi lapangan, telaah dokumen, dan studi literatur. Responden yang digunakan pada penelitian ini yaitu seluruh PKL yang berada di kawasan penelitian sejumlah 55 PKL. Jumlah sampel ini adalah semua PKL yang berjualan dan ditemui di Kota Lama selama melakukan survei lapangan. Setelah adanya pandemi Covid-19, kegiatan wisata maupun aktivitas penunjang di Kota Lama cenderung berkurang, sehingga hanya 55 PKL yang kemudian berjualan. Penentuan jumlah responden tersebut ditentukan berdasarkan penentuan besaran sampel yang dikemukakan oleh Yount dalam Pangastuti (2017), yaitu apabila besaran populasi 0-100 maka besaran sampel yang diambil adalah $100 \%$.

Metode analisis pada penelitian ini yaitu analisis deskriptif, analisis kebijakan penataaan PKL pasca revitalisasi, dan analisis spasial. Analisis deskriptif digunakan untuk mengidentifikasi sekaligus mendeskripsikan karakteristik PKL di Kota Lama Semarang. Sementara itu, analisis kebijakan 
penataan PKL pasca revitalisasi dilakukan untuk untuk menganalisis kesesuain kondisi riil di lokasi penelitian dengan kebijakan penataan PKL yang diterapkan di Kota Lama Semarang, serta pengaruh yang ditimbulkan dari kebijakan penataan PKL yang diterapkan terhadap aktivitas PKL. Adapun analisis spasial dilakukan dengan melakukan overlay peta untuk melihat perubahan karakteristik berlokasi PKL antara sebelum dengan setelah revitalisasi.

\section{HASIL DAN PEMBAHASAN}

\subsection{Karakteristik Pelaku Usaha PKL}

Karakteristik pelaku usaha PKL di Kota Lama Semarang khususnya pasca revitalisasi dilihat berdasarkan jenis kelamin, usia, tingkat pendidikan, asal daerah, lama bekerja sebagai PKL, alasan bekerja sebagai PKL, modal usaha, dan tingkat pendapatan yang dijelaskan sebagai berikut:

a. PKL mayoritas berjenis kelamin laki-laki (65\%) sementara $35 \%$ lainnya merupakan PKL perempuan. Hal tersebut sejalan dengan yang dikemukakan oleh Gallaway \& Bernasek (2002) dalam Nazara (2010), bahwa kecenderungan pekerja baik yang bekerja pada sektor formal maupun sektor informal mayoritas adalah pekerja laki-laki. Kecenderungan pekerja berjenis kelamin laki-laki disebabkan karena adanya tuntutan laki-laki sebagai kepala rumah tangga untuk memenuhi kebutuhan ekonomi keluarganya. Hal ini juga dipengaruhi oleh perbedaan karakteristik PKL perempuan yang lebih menekankan pada aspek interaksi sosial dibandingkan aspek ekonomi, sedangkan PKL laki-laki lebih menitikberatkan pada aspek ekonomi yang bersifat capital-based (Kawarazuka dkk., 2018). PKL laki-laki lebih banyak menjual barang yang lebih tahan lama dan memiliki mobilitas lebih tinggi, sedangkan PKL perempuan menjual barang dengan volume lebih sedikit, barang yang mudah rusak (misal makanan), investasi yang rendah, dan juga lebih rentan terhadap razia (Kawarazuka dkk., 2018; Njaya \& Murungwa, 2016). Namun, meskipun jumlah PKL perempuan lebih sedikit dari pada jumlah PKL laki-laki, adanya PKL perempuan tersebut menandakan bahwa perempuan juga turut berkontribusi dalam meningkatkan perekonomian keluarganya (Harahap, 2016).

b. PKL didominasi oleh kelompok usia produktif (15-64 tahun) yaitu sebesar 95\% sedangkan 5\% lainnya merupakan kelompok usia non produktif ( $>64$ tahun). Dominasi usia PKL lakilaki berada pada rentang 36-65 tahun, sementara dominasi usia PKL perempuan pada rentang 26-35 tahun. Mayoritas PKL di Kota Lama Semarang yang berada pada kelompok usia produktif tersebut menunjukkan bahwa terdapat kesesuaian kondisi yang terjadi dengan penelitian yang dikemukakan oleh Feige dalam Ojeda and Pino (2019), yaitu sektor informal menjadi alternatif bagi para pekerja yang tidak dapat bekerja pada sektor formal yang dibuktikan dengan besarnya persentase kelompok usia produktif PKL yang berada di Kota Lama Semarang.

c. Tingkat pendidikan PKL didominasi oleh lulusan SMP atau sederajat (35\%), kemudian diikuti oleh lulusan SD atau sederajat (29\%), lulusan SMA atau sederajat (27\%), tidak bersekolah (7\%), dan lulusan perguruan tinggi (2\%). Tingkat pendidikan PKL di Kota Lama Semarang tersebut sesuai dengan yang dikemukakan oleh Rothenberg dkk. (2016), yaitu sebagian besar PKL memiliki tingkat pendidikan yang rendah. Tidak diperlukannya keahlian atau keterampilan khusus yang harus didapatkan di bangku sekolah atau perguruan tinggi menyebabkan pekerjaan ini dapat diakses oleh berbagai latar belakang pendidikan. Sementara itu, keberadaan PKL dengan tingkat pendidikan yang tinggi dipengaruhi oleh sempitnya lapangan pekerjaan dan kurangnya kemampuan atau keahlian pekerja untuk bekerja pada sektor formal (Al-Jundi dkk., 2020).

d. PKL di Kota Lama Semarang mayoritas adalah penduduk asli Kota Semarang (64\%), sementara sisanya merupakan pendatang dari kota/kabupaten lainnya di Provinsi Jawa Tengah (22\%), dan dari luar Provinsi Jawa Tengah (15\%). Para pendatang tersebut mayoritas sudah bertempat tinggal di Kota Semarang selama lebih dari 11 tahun. Alasan para pendatang tersebut pindah ke Kota Semarang di antaranya adalah karena untuk mencari nafkah dan karena menikah sehingga harus tinggal mengikuti kota tempat tinggal pasangan. 
e. Mayoritas PKL di Kota Lama Semarang baru bekerja sebagai PKL selama 3 tahun atau kurang (60\%), sementara sisanya sudah berjualan selama 11 tahun atau lebih (22\%), dan 4 sampai 10 tahun (18\%). Peningkatan jumlah PKL di Kota Lama Semarang diketahui mulai terjadi pada tahun 2018 dan mengalami peningkatan yang sangat signifikan pada tahun 2020. Peningkatan tersebut terjadi karena adanya pengaruh dari kegiatan revitalisasi yang menyebabkan terjadinya peningkatan jumlah kunjungan wisatawan yang kemudian menjadi daya tarik bagi para PKL untuk berjualan di kawasan tersebut, serta pengaruh dari adanya pandemik Covid-19 yang mulai marak terjadi pada tahun 2020 yang menyebabkan banyaknya pekerja yang kehilangan pekerjaan dan beralih menjadi PKL.

f. Alasan bekerja sebagai PKL didominasi oleh alasan "kemungkinan mendapatkan penghasilan sebagai PKL" (42\%) dan "tidak ada pekerjaan lain" (36\%), sementara sisanya adalah karena "tidak punya keahlian/ keterampilan lain" (13\%), "tidak punya modal" (5\%), dan "kegiatan turun temurun" (4\%). Dominasi alasan tersebut terjadi karena pengaruh dari rendahnya tingkat Pendidikan, kurangnya daya saing untuk bekerja pada sektor formal, dan pengaruh pasca revitalisasi Kota Lama Semarang, serta pandemi Covid-19 yang menyebabkan pekerja kehilangan pekerjaan sebelumnya yang kemudian beralih menjadi PKL.

g. Modal per bulan sebagian besar PKL di Kota Lama Semarang tergolong rendah, yaitu Rp2.800.000 atau kurang dan bahkan tidak mengeluarkan modal sama sekali karena usaha milih orang lain (63\%). Kondisi tersebut terjadi karena kegiatan PKL yang dilakukan pada Kota Lama Semarang sebagian besar dilakukan oleh kelompok miskin kota yang memilih beraktivitas sebagai PKL bukan untuk mencari keuntungan melainkan untuk bertahan hidup.

h. Pendapatan bersih PKL di Kota Lama Semarang perbulannya sebagian besar di bawah UMK Semarang atau kurang dari Rp2.800.000 (49\%) sehingga tingkat pendapatannya tergolong rendah. Kondisi tersebut sesuai dengan yang dikemukakan oleh Rothenberg dkk. (2016), bahwa karakteristik sektor informal yang salah satu bentuknya yaitu PKL merupakan usaha dengan tingkat pendapatan yang rendah dan sebagian besar PKL pada dasarnya berjualan bukan untuk mencari keuntungan melainkan untuk memenuhi kebutuhan hidup sehari-hari.

\subsection{Karakteristik Aktivitas PKL}

Karakteristik aktivitas PKL di Kota Lama Semarang khususnya pasca revitalisasi dilihat berdasarkan jenis dagangan, sifat pelayanan, sarana usaha, waktu operasional, durasi kegiatan, dan pola persebaran yang dijelaskan sebagai berikut:

a. Jenis dagang PKL mayoritas adalah makanan dan minuman siap konsumsi (65\%), kemudian diikuti barang non-makanan (29\%), jasa (4\%), dan bahan makanan tidak diolah dan setengah jadi (2\%). Jenis dagang tersebut dipengaruhi oleh aktivitas utama di kawasan yang di antaranya yaitu aktivitas rekreasi dan perdagangan.

b. Sifat pelayanan PKL mayoritas adalah keliling (56\%), kemudian diikuti oleh PKL menetap (31\%), dan semi menetap (13\%). Dominasi PKL keliling tersebut disebabkan karena adanya larangan berjualan PKL di Kota Lama Semarang pasca revitalisasi yang menyebabkan para PKL harus berpindah dari satu tempat ke tempat lainnya.

c. Sarana usaha PKL di Kota Lama Semarang sebagian besar berupa pikulan/ keranjang (24\%), yang kemudian diikuti PKL tanpa sarana usaha (22\%), dan gerobak dorong (15\%), sementara itu sarana usaha berupa mobil, motor roda tiga, dan kios hanya memiliki persentase $2 \%$. Dominasi PKL yang berjualan dengan pikulan/keranjang dan tanpa sarana usaha disebabkan karena adanya penataan PKL di Kota Lama Semarang berupa penertiban yang dapat terjadi sewaktu-waktu, sehingga para PKL menyesuaikan sarana usahanya untuk mencegah dari terjadinya penyitaan barang dagangan.

d. Waktu operasional PKL mayoritas adalah dari sore hingga malam hari (33\%) dan siang hingga malam hari (22\%). Dominasi waktu operasional tersebut disebabkan karena pasca revitalisasi Kota Lama Semarang kunjungan wisatawan cenderung ramai pada sore hingga malam hari yang menyebabkan para PKL cenderung 
berjualan pada waktu-waktu tersebut. Kondisi tersebut sesuai dengan penelitian yang dilakukan oleh Ojeda and Pino (2019) dan Suryanto dkk. (2020) yang menyebutkan bahwa salah satu karakteristik PKL yaitu cenderung berjualan pada waktu ramai pengunjung.

e. Durasi kegiatan PKL mayoritas adalah 1-6 jam (42\%) dan 6-12 jam (47\%), sedangkan sisanya merupakan PKL yang berjualan lebih dari 12 jam (11\%). Kondisi tersebut terjadi karena mayoritas PKL cenderung berjualan pada waktu ramai pengunjung dan pada lokasi yang juga ramai dikunjungi oleh pengunjung. Sementara itu, PKL yang berjualan lebih dari 12 jam cenderung berjualan di lokasi yang tergolong aman dari pengawasan petugas sehingga dapat berjualan lebih lama tanpa harus merasa terancam dari kegiatan penertiban yang dapat terjadi sewaktu-waktu.

f. Pola persebaran PKL di Kota Lama Semarang adalah focus agglomeration, yang terpusat di sekitar Taman Srigunting dan persimpangan Jalan Suari dengan Jalan Kepodang (lihat Gambar 2). Focus agglomeration merupakan pola persebaran yang berkelompok, seperti pada taman, tepi pasar, dan sebagainya (McGee \& Yeung, 1977). Konsentrasi PKL lebih banyak berada di sekitar Taman Srigunting karena pengaruh dari akumulasi pengunjung yang lebih banyak berada di sekitar Taman Srigunting. (a) Pola Sebaran PKL di sekitar Taman Srigunting

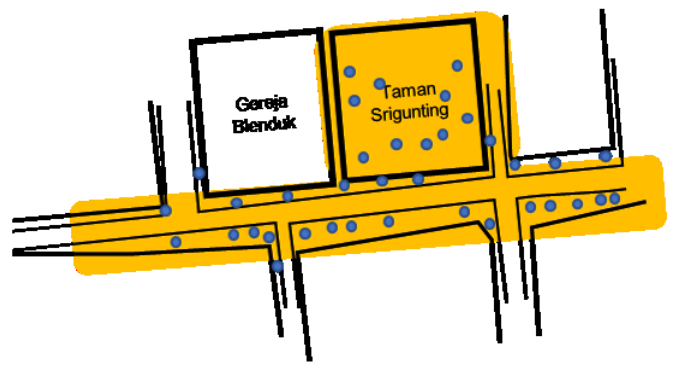

(b) Pola Sebaran PKL di sekitar Lapangan Jalan Kepodang dan Jalan Suari

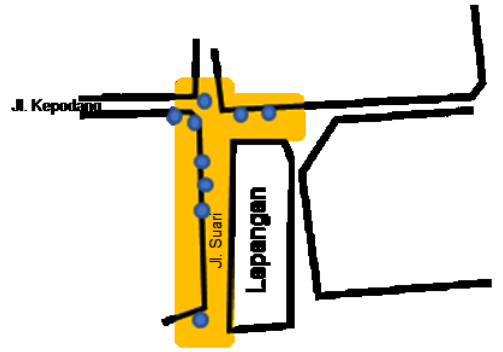

Gambar 2. Pola Persebaran PKL Kota Lama Semarang

\subsection{Kebijakan Penataan PKL Pasca Revitalisasi}

Identifikasi kebijakan penataan PKL pasca revitalisasi Kota Lama Semarang ditunjukkan pada Tabel 1. Berdasarkan hasil wawancara dengan pihak BPK2L diketahui bahwa PKL dilarang berjualan di Kota Lama Semarang pasca revitalisasi yang ditegaskan dengan adanya papan penanda larangan berjualan yang tersebar di beberapa titik lokasi. Sementara itu, berdasarkan hasil wawancara dengan pihak Dinas Perindustrian Kota Semarang, salah satu bentuk penataan yang dilakukan adalah dengan memformalkan PKL khususnya dalam hal lokasi berjualannya, pasca revitalisasi para PKL barang antik yang sebelumnya berjualan di Jalan Taman Srigunting tersebut direlokasi ke gedung Galeri Industri Kreatif (sekarang Semarang Creative Hub). Para PKL yang diformalkan oleh pemerintah sebagai upaya penataan tersebut kini termasuk sebagai UMKM, yang merupakan usaha produktif yang dikelola baik oleh perorangan atau badan usaha yang bukan merupakan anak perusahaan atau bukan cabang perusahaan yang memenuhi kriteria yang dimaksud dalam Undang-Undang Nomor 20 Tahun 2008 Tentang Usaha Mikro, Kecil, Dan Menengah. Pasca revitalisasi para pedagang barang antik tersebut kegiatannya sudah terdaftar di Dinas Perindustrian Kota Semarang serta lokasi berjualannya sudah tidak berada di ruang publik, sehingga para pedagang tersebut tidak dapat dikategorikan sebagai PKL mengingat karakteristik PKL di antaranya yaitu merupakan kegiatan penawaran barang dan atau jasa yang dilakukan oleh perorangan atau keluarga pada ruang publik, terutama pada jalan dan trotoar (McGee \& Yeung, 1977) dan juga tidak teregistrasi secara formal.

Hasil wawancara lainnya dengan pihak Dinas Perindustrian Kota Semarang yaitu bahwa pedagang barang antik yang direlokasi sudah disediakan tempat beserta sarana usaha berupa 
meja/jongko dengan ukuran $1,35 \times 1,5 \mathrm{~m}$, dan dilengkapi dengan listrik. Para pedagang barang antik tersebut dapat menggunakan gedung beserta sarana usaha dan listrik secara gratis dengan syarat para pedagang tersebut sudah terdaftar di Dinas Perindustrian Kota Semarang. Sementara itu, kondisi riil PKL di Kota Lama Semarang tersebar hampir di seluruh jalan di Kota Lama Semarang, dengan konsentrasi paling banyak berada di Jalan Letjen Suprapto khususnya di sekitar Taman Srigunting. Kondisi tersebut tentunya tidak sesuai dengan kebijakan larangan berjualan bagi para PKL pasca revitalisasi Kota Lama Semarang, sebagaimana disebutkan oleh pihak BPK2L dalam kegiatan wawancara.
Para PKL yang masih dapat ditemui di ruang publik pasca revitalisasi Kota Lama Semarang mayoritas berjualan setiap hari dari sore hingga malam hari, dengan barang dagang berupa makanan minuman siap konsumsi (telur gulung, es teh, air mineral, dan lain-lain) dan barang non-makanan (balon). Sarana usaha yang digunakan oleh para PKL tersebut mayoritas adalah sarana usaha yang mudah dibawa seperti pikulan/ keranjang dan tanpa sarana usaha, sehingga dalam kegiatannya para PKL tersebut tidak membutuhkan luasan lahan atau tempat kegiatan dan fasilitas dasar seperti air ataupun listrik. Sementara itu, terkait biaya retribusi diketahui bahwa mayoritas PKL tidak membayar retribusi pada saat berjualan di Kota Lama Semarang pasca revitalisasi.

Tabel 1. Identifikasi Kebijakan Penataan PKL Pasca Revitalisasi

\begin{tabular}{|c|c|c|c|c|}
\hline \multirow[b]{2}{*}{ No } & \multirow[b]{2}{*}{ Variabel } & \multirow{2}{*}{$\begin{array}{c}\text { Kondisi Riil } \\
\text { PKL }\end{array}$} & \multicolumn{2}{|c|}{ Kebijakan Penataan PKL } \\
\hline & & & $\begin{array}{l}\text { Dinas Perindustrian Kota } \\
\text { Semarang }\end{array}$ & BPK2L \\
\hline 1 & Lokasi PKL & $\begin{array}{l}\text { Taman Srigunting, Jalan Letjen } \\
\text { Suprapto, Jalan Gelatik, Jalan } \\
\text { Kepodang, Jalan Sendowo, Jalan } \\
\text { Garuda, Jalan Nuri, Jalan Branjangan, } \\
\text { Jalan Empu Tantular }\end{array}$ & $\begin{array}{l}\text { UMKM barang antik yang } \\
\text { sebelumnya merupakan PKL } \\
\text { direlokasi ke salah satu bagian } \\
\text { dalam gedung Galeri Industri } \\
\text { Kreatif (sekarang Semarang } \\
\text { Creative Hub) }\end{array}$ & \multirow{7}{*}{$\begin{array}{l}\text { PKL dilarang } \\
\text { berjualan di } \\
\text { Kota Lama } \\
\text { Semarang } \\
\text { yang } \\
\text { ditegaskan } \\
\text { dengan } \\
\text { adanya } \\
\text { papan } \\
\text { penanda } \\
\text { larangan } \\
\text { berjualan } \\
\text { yang } \\
\text { tersebar } \\
\text { pada } \\
\text { beberapa } \\
\text { titik lokasi }\end{array}$} \\
\hline 2 & $\begin{array}{l}\text { Waktu } \\
\text { operasional }\end{array}$ & $\begin{array}{l}\text { Mayoritas berjualan setiap hari pada } \\
\text { sore hingga malam hari }\end{array}$ & $\begin{array}{l}\text { Pagi hingga malam hari }(10.00- \\
22.00 \text { WIB) }\end{array}$ & \\
\hline 3 & $\begin{array}{l}\text { Jenis barang atau } \\
\text { jasa }\end{array}$ & $\begin{array}{l}\text { Mayoritas penjual makanan dan } \\
\text { minuman siap konsumsi, dan barang } \\
\text { non-makanan }\end{array}$ & $\begin{array}{l}\text { Barang non-makanan (barang } \\
\text { antik) }\end{array}$ & \\
\hline 4 & $\begin{array}{l}\text { Jenis sarana } \\
\text { usaha }\end{array}$ & $\begin{array}{l}\text { Mayoritas pikulan/keranjang, dan } \\
\text { tanpa sarana usaha }\end{array}$ & Meja/jongko & \\
\hline 5 & $\begin{array}{l}\text { Ukuran lahan } \\
\text { atau tempat } \\
\text { kegiatan } \\
\end{array}$ & $\begin{array}{l}\text { Mayoritas tidak menggunakan lahan } \\
\text { atau tempat kegiatan secara menetap }\end{array}$ & $1,35 \times 1,5 \mathrm{~m}$ & \\
\hline 6 & $\begin{array}{l}\text { Ketersediaan } \\
\text { fasilitas dasar }\end{array}$ & $\begin{array}{l}\text { Mayoritas tidak menggunakan fasilitas } \\
\text { dasar. Namun, PKL yang menggunakan } \\
\text { fasilitas dasar seperti air dan listrik } \\
\text { harus membayar atau membeli sendiri }\end{array}$ & Listrik & \\
\hline 7 & Biaya retribusi & $\begin{array}{l}\text { Mayoritas PKL tidak membayar } \\
\text { retribusi }\end{array}$ & Gratis & \\
\hline
\end{tabular}

\subsection{Karakteristik Berlokasi PKL Pasca Revitalisasi}

Karakteristik berlokasi PKL dapat dilihat berdasarkan kedekatan tempat tinggal PKL dan pemilihan lokasi berjualan PKL. Kedekatan tempat tinggal dilihat berdasarkan jarak tempuh, waktu tempuh, dan moda transportasi yang digunakan oleh PKL. Sementara itu, pemilihan lokasi berjualan PKL dilihat berdasarkan tingkat kepadatan atau akumulasi pengunjung yang tinggi, ukuran lahan atau tempat kegiatan yang digunakan, fasilitas dasar yang digunakan, biaya retribusi yang dikeluarkan, aksesibilitas lokasi, aktivitas di sekitar 
lokasi, dan adanya peraturan atau kebijakan yang mengatur PKL.

Analisis pengaruh kedekatan tempat tinggal PKL meliputi jarak, waktu tempuh, dan moda transportasi yang digunakan dari tempat tinggal ke lokasi berjualan pada penelitian ini dilakukan dengan mengelompokkan PKL berdasarkan literatur yang dikemukakan oleh McGee and Yeung (1977), dengan hasil sebagai berikut:

a. Jarak tempat tinggal PKL dengan lokasi berjualan mayoritas berada dalam jarak yang relative dekat yaitu pada rentang 1-2,99 km (58\%). Kondisi tersebut terjadi karena sebagian besar PKL Kota Lama Semarang merupakan penduduk asli Kota Semarang yang bertempat tinggal di dekat Kota Lama Semarang dan pendatang yang memilih bertempat tinggal di dekat Kota Lama Semarang.

b. Waktu tempuh PKL dari tempat tinggal menuju lokasi berjualannya mayoritas adalah 10 menit atau kurang (51\%). Kondisi tersebut sesuai dengan jarak tempat tinggal PKL yang relatif dekat dengan lokasi berjualan.

c. Moda transportasi PKL mayoritas adalah kendaraan bermotor (49\%). Kondisi tersebut sesuai dengan yang dikemukakan oleh McGee and Yeung (1977), bahwa meskipun jarak tempat tinggal ke lokasi berjualan relatif dekat, adanya jarak dari tempat tinggal ke lokasi berjualan tersebut mendorong PKL untuk menggunakan kendaraan yang lebih mekanis.

Sementara itu, berdasarkan hasil analisis terhadap pemilihan lokasi berjualan PKL Kota Lama Semarang diketahui bahwa sebagian besar PKL berjualan di Taman Srigunting dan sekitarnya. Konsentrasi PKL yang cenderung berada di Taman Srigunting dan sekitarnya tersebut dikarenakan adanya berbagai aktivitas seperti ruang terbuka hijau, restoran, kafe, gereja, dan minimarket di sekitar Taman Srigunting. Selain itu, di sekitar Taman Srigunting juga menjadi salah satu spot foto bagi para pengunjung karena terdapat landmark kawasan, dan juga letak Taman Srigunting yang memiliki tingkat aksesibilitas yang tinggi karena berlokasi di Jalan Letjen Suprapto yang tergolong jalan arteri menjadikan lokasi Taman Srigunting ini ramai dikunjungi pengunjung, sehingga terdapat akumulasi pengunjung di sekitar lokasi tersebut.
Oleh sebab itu, dapat dikatakan bahwa PKL di Kota Lama Semarang cenderung berlokasi pada Taman Srigunting dan sekitarnya karena terdapat berbagai aktivitas di sekitar Taman Srigunting, terdapat landmark kawasan, dan memiliki aksesibilitas tinggi karena terletak di jalan arteri, yang kemudian menyebabkan adanya konsentrasi atau akumulasi pengunjung pada lokasi tersebut. Pemilihan lokasi PKL di Kota Lama Semarang tersebut sesuai dengan yang dikemukakan oleh (Ojeda and Pino (2019); Perdana dkk. (2020); Suryanto dkk. (2020); Widjajanti (2015)), bahwa karakteristik pemilihan lokasi PKL di antaranya dipengaruhi oleh lokasinya atau karakter tempat, aktivitas di sekitar lokasi, pada lokasi dengan berbagai pusat kegiatan (mixed use area), kemudahan akses, dan terdapat akumulasi pengunjung.

Hasil analisis pemilihan lokasi berjualan PKL Kota Lama Semarang lainnya yaitu terkait karakteristik pemilihan lokasi berjualan PKL berdasarkan jenis dagang, sifat pelayanan, sarana usaha, dan waktu operasional yang dijelaskan sebagai berikut:

a. PKL penjual makanan minuman siap konsumsi, barang non-makanan, dan penyedia jasa (foto dan tambal ban) mayoritas berada di sekitar Taman Srigunting dan di persimpangan Jalan Kepodang dengan Jalan Suari karena pengaruh aktivitas di sekitar lokasi. Sementara itu, PKL penjual bahan mentah dan setengah jadi berjualan di persimpangan Jalan Sendowo karena lokasinya yang cukup dekat dengan permukiman. Pemilihan lokasi PKL berdasarkan jenis dagangan yang dipengaruhi oleh aktivitas di sekitar lokasinya ini sesuai yang dikemukakan oleh McGee and Yeung (1977), bahwa jenis dagangan PKL dipengaruhi oleh aktivitas atau kegiatan di sekitar lokasinya.

b. PKL dengan sifat layanan keliling dan sarana usaha berupa pikulan atau keranjang dan tanpa sarana usaha mayoritas berada di sekitar Taman Srigunting karena dipengaruhi oleh kebijakan penataan PKL pasca revitalisasi sehingga para PKL menyesuaikan kegiatannya agar dapat tetap berjualan di pusat keramaian pengunjung dengan sarana usaha yang mudah dibawa dan sifat layanan keliling agar dapat dengan mudah menghindar dari kegiatan penertiban. Sementara itu, PKL yang sifat 
layanannya menetap dengan sarana usaha berupa kios, warung semi permanen, ataupun sarana usaha lainnya yang menetap pada satu lokasi cenderung memilih berjualan di luar Jalan Letjen Suprapto (Jalan Gelatik, Lapangan Parkir Jalan Branjangan, Jalan Suari, Jalan Kepodang, dan Jalan Sendowo), hal ini disebabkan karena di sepanjang Jalan Letjen Suprapto khususnya di sekitar Taman Srigunting merupakan lokasi yang sangat ketat pengamanannya karena adanya petugas keamanan yang melarang PKL untuk berjualan.

c. PKL dengan waktu operasional siang/ sore hingga malam hari cenderung berlokasi di sekitar Taman Srigunting karena pengaruh dari aktivitas di sekitarnya seperti rekreasi dan perdagangan yang mulai ramai dikunjungi pengunjung pada waktu-waktu tersebut. Sementara itu, PKL yang waktu operasionalnya sore sampai subuh dan 24 jam cenderung berada di sekitar permukiman dan tempat kegiatan yang beroperasi hingga subuh seperti tempat karaoke, serta restoran dan bar yaitu pada Jalan Sendowo. Adapun PKL dengan waktu operasional lainnya, seperti pada pagi hingga siang atau pagi hingga sore cenderung berlokasi di dekat aktivitas perkantoran, parkiran, dan pertokoan, yaitu pada Jalan Kepodang, Jalan Gelatik, Jalan Letjen Suprapto (seberang parkiran), dan Jalan Sendowo. Berdasarkan waktu operasional PKL tersebut dapat diketahui bahwa waktu operasional PKL menyesuaikan dengan waktu aktivitas di sekitar lokasi (Widjajanti \& Damayanti, 2020).
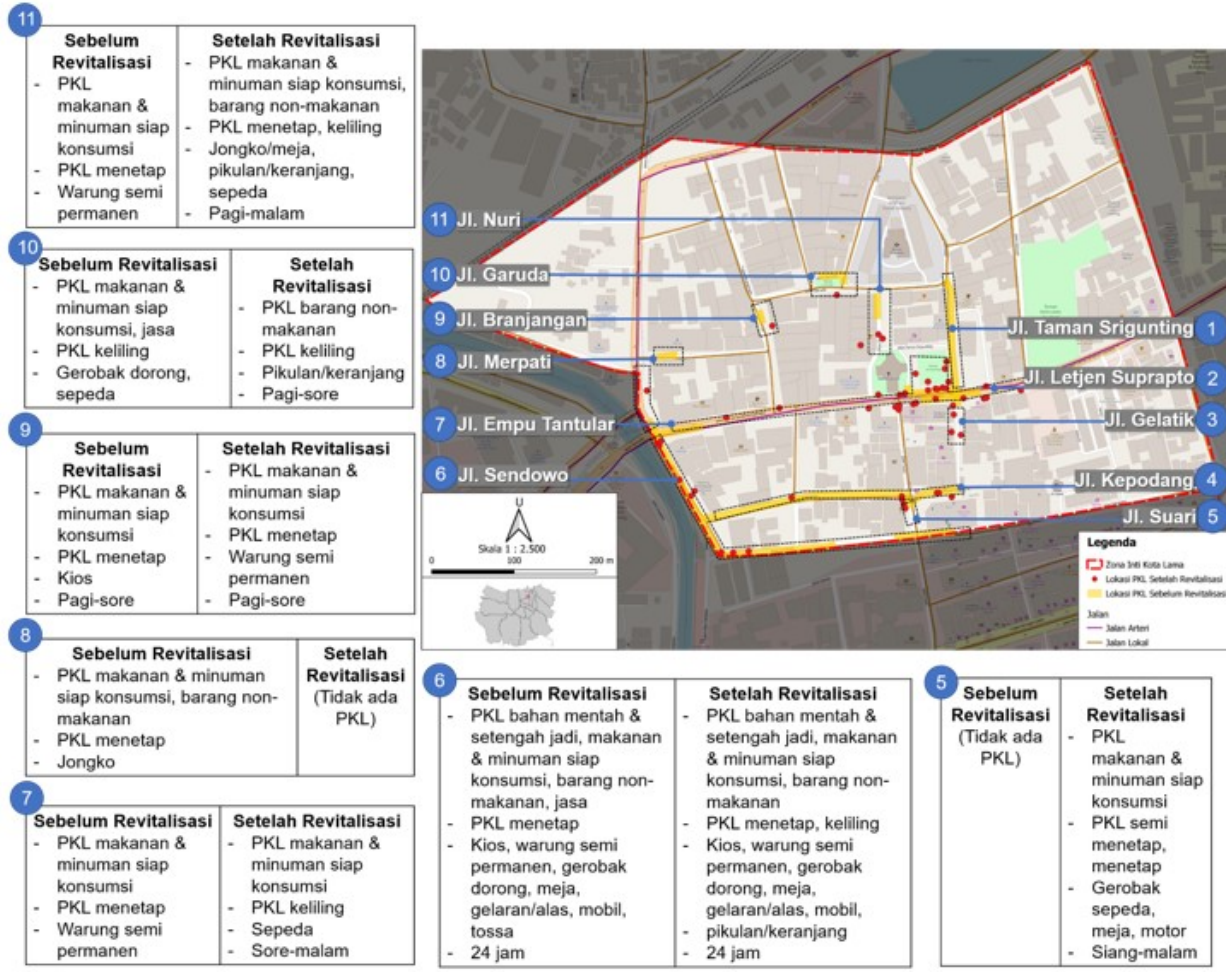

\begin{tabular}{|c|c|c|}
\hline \multicolumn{2}{|c|}{$\begin{array}{l}\text { Sebelum Revitalisasi } \\
\text { PKL barang antik/ } \\
\text { seni } \\
\text { - PKL menetap } \\
\text { - Kios } \\
\text { - Pagi-malam }\end{array}$} & $\begin{array}{l}\text { Setelah Revitalisasi } \\
\text { (Tidak ada PKL) }\end{array}$ \\
\hline \multicolumn{2}{|c|}{$\begin{array}{l}\text { Sebelum Revitalisasi } \\
\text { - PKL makanan \& } \\
\text { minuman siap } \\
\text { konsumsi, barang } \\
\text { non-makanan, jasa } \\
\text { - PKL menetap, semi } \\
\text { menetap } \\
\text { - Warung semi } \\
\text { permanen, jongko, } \\
\text { gerobak dorong, } \\
\text { motor } \\
\text { - Pagi-malam }\end{array}$} & $\begin{array}{l}\text { Setelah Revitalisasi } \\
\text { - PKL makanan \& } \\
\text { minuman siap } \\
\text { konsumsi, barang } \\
\text { non-makanan, jasa } \\
\text { - PKL kelling, } \\
\text { menetap } \\
\text { - Pikulan/keranjang, } \\
\text { tanpa sarana } \\
\text { usaha, sepeda, } \\
\text { motor, gerobak } \\
\text { dorong } \\
\text { - Pagi-malam }\end{array}$ \\
\hline \multicolumn{2}{|l|}{\begin{tabular}{l|l} 
& \multicolumn{1}{c}{ Sebelum } \\
Revitalisasi & \\
- PKL makanan & - \\
\& minuman \\
siap konsumsi \\
- PKL keliling \\
- Gerobak \\
dorong
\end{tabular}} & $\begin{array}{l}\text { Setelah Revitalisasi } \\
\text { PKL makanan \& minuman } \\
\text { siap konsumsi, jasa } \\
\text { - PKL menetap } \\
\text { Warung semi permanen, } \\
\text { gerobak dorong } \\
\text { Pagi-malam }\end{array}$ \\
\hline \multicolumn{2}{|c|}{$\begin{array}{l}\text { Sebelum Revitalisasi } \\
\text { - PKL makanan \& } \\
\text { minuman siap } \\
\text { konsumsi, barang } \\
\text { non-makanan } \\
\text { - PKL menetap } \\
\text { - Warung semi } \\
\text { permanen, meja } \\
\text { - Pagi-malam }\end{array}$} & $\begin{array}{l}\text { Setelah Revitalisasi } \\
\text { PKL makanan \& } \\
\text { minuman siap } \\
\text { konsumsi } \\
\text { PKL keliling, } \\
\text { menetap } \\
\text { - Gerobak dorong, } \\
\text { gerobak sepeda, } \\
\text { motor roda tiga } \\
\text { - Pagi-malam }\end{array}$ \\
\hline
\end{tabular}

Gambar 3. Peta Karakteristik Berlokasi PKL Sebelum dan Setelah Revitalisasi

Pemilihan lokasi PKL Kota Lama Semarang antara sebelum dengan setelah revitalisasi ditunjukkan pada Gambar 3. Pada Gambar 3 terlihat perbedaan lokasi PKL sebelum dan setelah revitalisasi, pasca revitalisasi mayoritas PKL berlokasi di sekitar Taman Srigunting, sedangkan sebelum revitalisasi PKL cenderung menyebar di sepanjang Jalan Taman Srigunting, Jalan Nuri, Jalan Garuda, Jalan Branjangan, Jalan Merpati, sepanjang Jalan
Sendowo, dan sepanjang Jalan Kepodang. Selain itu, pada Gambar 3 juga dapat terlihat bahwa terdapat perbedaan karakteristik PKL ketika berjualan pada masing-masing lokasi antara sebelum dengan setelah revitalisasi Kota Lama Semarang, yang salah satunya ditunjukkan pada Jalan Kepodang, dimana sebelum revitalisasi jenis dagang yang ditawarkan yaitu makanan minuman siap konsumsi dan barang non-makanan, dengan 
sifat layanan mayoritas menetap dan sarana usaha berupa warung semi permanen serta meja, sedangkan pasca revitalisasi PKL hanya menjual makanan minuman siap konsumsi saja, dengan sifat layanan mayoritas adalah keliling dan sarana usaha berupa gerobak dorong, gerobak sepeda, dan motor roda tiga.

Selanjutnya berdasarkan Gambar 3 juga dapat terlihat lokasi yang paling terdampak dari kegiatan revitalisasi, yaitu Jalan Taman Srigunting, Jalan Merpati, dan Jalan Suari. Kegiatan PKL pada Jalan Taman Srigunting dan Jalan Merpati hanya dapat ditemui saat sebelum revitalisasi, sedangkan kegiatan PKL di Jalan Suari baru muncul pasca revitalisasi Kota Lama Semarang. Kondisi tersebut terjadi disebabkan karena keberadaan kebijakan berupa relokasi dan penertiban PKL, serta pengaruh dari perbaikan fisik kawasan yang mempengaruhi aktivitas di sekitar lokasi.

\section{KESIMPULAN}

Kegiatan revitalisasi Kota Lama Semarang yang dilakukan dalam rangka menghidupkan kembali kawasan turut mempengaruhi PKL dalam berlokasi di kawasan bersejarah tersebut. $\mathrm{Hal}$ ini dikarenakan dua faktor yang saling bertolak belakang, yaitu di satu sisi terdapat kebijakan penataan PKL berupa larangan berjualan, namun di sisi lain lokasi Kota Lama Semarang pasca revitalisasi menjadi lokasi yang menarik bagi para PKL untuk berjualan. Akibat kedua faktor tersebut, para PKL menyesuaikan cara berjualan mereka untuk meminimalkan kemungkinan terkena penyitaan barang saat dilakukannya kegiatan penertiban secara tiba-tiba. Hasil analisis secara umum menunjukkan bahwa kegiatan revitalisasi mempengaruhi karakteristik berlokasi PKL, hal ini ditunjukkan dengan adanya perubahan pada jenis dagangan, sifat layanan, sarana usaha, dan waktu operasional PKL. Hal inilah yang membedakan karakteristik PKL sebelum dan sesudah revitalisasi.

Konsentrasi PKL pasca revitalisasi cenderung berada di sekitar Taman Srigunting karena keberadaan berbagai aktivitas di sekitar lokasi, dekat dengan jalan arteri, dan terdapat landmark kawasan yang menyebabkan tingginya konsentrasi pengunjung, namun pada lokasi tersebut pengawasan yang dilakukan terhadap PKL cukup ketat sehingga karakteristik berlokasi para PKL di lokasi tersebut disesuaikan untuk meminimalkan kemungkinan terkena penyitaan barang dagangan. Adapun hasil penelitian lainnya yaitu terkait lokasi yang diminati oleh PKL, adalah pada trotoar, persimpangan jalan, taman, jalan utama, serta jalan penghubung kawasan yang terdapat kepadatan pejalan kaki, pada lokasi yang memiliki berbagai aktivitas di sekitarnya, pada lokasi yang terdapat akumulasi pengunjung, dan pada lokasi yang terdapat kelonggaran pengawasan petugas yang mengawasi PKL. Berdasarkan hasil penelitian terdapat rekomendasi yang dapat diberikan, yaitu kebijakan penataan PKL perlu memperhitungkan PKL sebagai bagian dalam rencana, yang di antaranya dapat dilakukan dengan menyediakan ruang aktivitas khusus sesuai karakteristik PKL, penetapan sarana dagang yang dapat digunakan oleh PKL untuk menghindari kesan kumuh pada kawasan dan melakukan pembinaan dan pelatihan PKL untuk meningkatkan kegiatan ekonomi kawasan sekaligus membantu meningkatkan perekonomian PKL.

\section{DAFTAR PUSTAKA}

Al-Jundi, S. A., Ali, M., Latan, H., \& Al-Janabi, H. A. (2020). The Effect of Poverty on Street Vending Through Sequential Mediations of Education, Immigration, and Unemployment. Sustainable Cities and Society, 62, 102316. Doi: https://doi.org/ 10.1016/j.scs.2020.102316

Deore, P., \& Lathia, S. (2019). Streets as Public Spaces: Lessons from Street Vending in Ahmedabad, India. Urban Planning, 4(2), 138-153. Doi: https://doi.org/10.17645/up.v4i2.2058

Harahap, E. F. (2016). Model Karakteristik dan Peranan Pekerja Informal di Kota Padang. Jurnal Apresiasi Ekonomi, 4(3), 169-176. Doi: https://doi.org/10.31846/jae.v4i3.161

Kawarazuka, N., Béné, C., \& Prain, G. (2018). Adapting to a New Urbanizing Environment: Gendered Strategies of Hanoi's Street Food Vendors. Environment and Urbanization, 30(1), 233-248. Doi: 
https://doi.org/10.1177/09562478177354 82

McGee, T. G., \& Yeung, Y.-m. (1977). Hawkers in Southeast Asian Cities: Planning for The Bazaar Economy: IDRC, Ottawa, ON, CA.

Nazara, S. (2010). Ekonomi Informal di Indonesia: Ukuran, Komposisi dan Evolusi: ILO.

Njaya, T., \& Murungwa, S. (2016). Why Do Female Street Vendors Earn Less Than Male Street Vendors in Harare. International Journal of Business and Management Invention, 5(11), 23-27.

Nogueira, M. (2021). The Ambiguous Labour of Hope: Affective Governance and The Struggles of Displaced Street Vendors in Belo Horizonte, Brazil. Environment and Planning D: Society and Space, 39(5), 863879. Doi: https://doi.org/10.1177/02637 758211032626

Ojeda, L., \& Pino, A. (2019). Spatiality of Street Vendors and Sociospatial Disputes Over Public Space: The Case of Valparaíso, Chile. Cities, 95, 102275. Doi: https://doi.org/ 10.1016/j.cities.2019.02.005

Pangastuti, R. L. (2017). The Influence of Experiential Marketing and Service Quality for being Reasonability of Customers Loyality Forming (Case Study of Beauty Saloon of London Beauty Center "LBC"). Jurnal Ekonomi Universitas Kadiri, 2(2), 198-213.

Doi: https://doi.org/10.30737/ekonika.v2i2.43

Perdana, E. A. L., Rahayu, P., \& Hardiana, A. (2020). Karakteristik Pedagang Kaki Lima dan Preferensinya Terhadap Lokasi Kawasan Solo Techno Park. Region: Jurnal Pembangunan Wilayah dan Perencanaan Partisipatif, 15(2), 172-188. Doi: https://doi.org/10.20961/region.v15i2.244 40

Rahayu, M. J., Buchori, I., Widjajanti, R., \& Putri, R. A. (2019). Mapping the Alternative Locations of Street Vendor Stabilization in Surakarta, Indonesia. Geoplanning: Journal of Geomatics and Planning, 6(1), 43-54. Doi: https://doi.org/10.14710/geoplanning .6.1.43-54

Roever, S., \& Skinner, C. (2016). Street Vendors and Cities. Environment and Urbanization,
28(2), 359-374. Doi: https://doi.org/ $10.1177 / 0956247816653898$

Rothenberg, A. D., Gaduh, A., Burger, N. E., Chazali, C., Tjandraningsih, I., Radikun, R., . . . Weilant, S. (2016). Rethinking Indonesia's Informal Sector. World Development, 80, 96-113. Doi: https://doi.org/10.1016/ j.worlddev.2015.11.005

Santos, M. D., Badua, R. D., Callo, C. G. C., \& Ferrer Jr, F. P. (2020). Street Vending Locations: The Determinants Affecting The Choice of Location of Street Vendors at Science City of Muñoz, Nueva Ecija. American International Journal of Business Management (AIJBM), 3(12), 57-62.

Suryanto, M. E., Adianto, J., \& Gabe, R. T. (2020). Accommodating The Informal Economy in Public Space. Urbani Izziv, 31(1), 89-100. Doi: https://doi.org/10.5379/urbani-izziven-2020-31-01-003

Todaro, M. P., \& Smith, S. C. (2006). Pembangunan Ekonomi Jilid 1 Edisi Kesembilan. Jakarta: Erlangga.

Turner, S., \& Zuberec, C. (2021). Visualizing Frictional Encounters: Analyzing and Representing Street Vendor Strategies in Vietnam Through Narrative Mapping. Applied Geography, 131, 102460. Doi: https://doi.org/10.1016/j.apgeog.2021.10 2460

Undang-Undang Nomor 20 Tahun 2008 tentang Usaha Mikro, K., dan Menengah.

Widjajanti, R. (2012). Karakteristik Aktivitas Pedagang Kaki Lima di Ruang Kota (Studi Kasus: Kawasan Pendidikan Tembalang, Kota Semarang). Jurnal Pembangunan Wilayah dan Kota, 8(4), 412-424. Doi: https://doi.org/10.14710/pwk.v8i4.6498

Widjajanti, R. (2015). Karakteristik Aktivitas Pedagang Kaki Lima di Pecinan, Semarang. Ruang, 1(2), 61-70. Doi: https://doi.org/ 10.14710/ruang.1.2.81-90

Widjajanti, R., \& Damayanti, M. (2020). Space Compatibility Based on Spatial Behavior of Street Vendors in Urban Public Space in Chinatown, Semarang. Paper presented at the IOP Conference Series: Earth and Environmental Science. 
Widjajanti, R., Sunarti, S., \& Tyas, W. P. (2017). Pola Sebaran Ruang Aktivitas PKL di Ruang Publik Kawasan Pecinan Semarang. TATALOKA, 19(3), 242-255. Doi: https://doi.org/10.14710/tataloka.19.3.24 2-255 